\title{
Evaluation of Three Electrochemical Dissolved Oxygen Meters
}

\author{
Noah J. Langenfeld ${ }^{1}$ and Bruce Bugbee ${ }^{1}$
}

AdDITIONAL INDEX WORDS. aquaponics, hydroponics, liquid culture, Smart Sensor Roeam AR8210, Sper Scientific 850048, water quality, Yellow Springs 550A

Summary. Dissolved oxygen (DO) is critical for aerobic life in aquatic environments. Rapid and accurate measurements of DO are necessary to quantify the rate of oxygen uptake and maintain optimum conditions in root zones. DO meters are available across a price range of USD99 to more than USD1000. We compared three meters for stability, response time, and accuracy in freshwater [tap water, $0 \mathrm{~g} \cdot \mathrm{L}^{-1}$ sodium chloride $(\mathrm{NaCl})$ ] and saline water (simulated seawater, $35 \mathrm{~g} \cdot \mathrm{L}^{-1} \mathrm{NaCl}$ ) across multiple temperatures. The Yellow Springs, Inc. 550A (YSI) and Sper Scientific 850048 (Sper) meters were stable across a range of water temperatures $\left(12-38^{\circ} \mathrm{C}\right)$ and salinity. The Smart Sensor Roeam AR8210 drifted $\pm \mathbf{5 0} \%$ within minutes after calibration and was not evaluated further. In freshwater, the YSI meter was within $4 \%$ and the Sper meter was within $5 \%$ of the theoretical value at 12 and $22{ }^{\circ} \mathrm{C}$. Meters were less accurate at $38^{\circ} \mathrm{C}$. The accuracy in saline water was similar to freshwater. Across temperature and salinity, the response time averaged $10 \mathrm{~s}$ for the YSI meter and $15 \mathrm{~s}$ for the Sper meter. We conclude that the YSI and Sper meters can provide rapid, stable, and accurate measurements of DO.

$\mathrm{D}$ issolved oxygen (DO) is the free oxygen available in solutions and is consumed in the metabolism of all aerobic organisms. DO concentration in water is used as an indicator of the health of ecosystems, and it varies with solution temperature, agitation, salinity, injection rate, and barometric pressure (AlRawahy et al., 2019; Wei et al., 2019). High temperatures and salinities decrease the capacity for DO.

Received for publication 29 Jan. 2021. Accepted for publication 29 Mar. 2021.

Published online 2 June 2021

${ }^{1}$ Department of Plants, Soils, and Climate, Utah State University, Crop Physiology Laboratory, 1410 N. 800 E., Logan, UT 84341

We acknowledge the four anonymous reviewers who provided helpful feedback to improve this manuscript and broaden its reach.

This research was supported by the Utah Agricultural Experiment Station, Utah State University, and approved as journal paper no. 9428; NASA, Center for the Utilization of Biological Engineering in Space (grant no. NNXI7AJ31G).

Mention of a trademark, proprietary product, or vendor does not constitute a guarantee or warranty of the product and does not imply its approval to the exclusion of other products or vendors that also may be suitable.

N.J.L. is the corresponding author. E-mail: noah.langenfeld@usu.edu.

This is an open access article distributed under the CC BY-NC-ND license (https://creativecommons. org/licenses/by-nc-nd/4.0/).

https://doi.org/10.21273/HORTTECH04819-21
Most DO meters have temperature ranges of 0 to $40^{\circ} \mathrm{C}$ and salinity ranges of 0 to $70 \mathrm{~g} \cdot \mathrm{L}^{-1}$ (typically from $\mathrm{NaCl}$ ). These ranges encompass environments ranging from arctic to tropical and from freshwater to seawater.

Demand for DO in respiration increases with biological density, metabolic rate, growth stage, and temperature. High biological demand requires greater inputs of oxygen to sustain homeostasis (BenNoah and Friedman, 2018). The nutrient solution of liquid hydroponics benefits from levels of DO close to saturation near $8 \mathrm{mg} \cdot \mathrm{L}^{-1}$. This promotes healthy root respiration and minimizes hypoxic microsites or the development of anaerobic bacteria (Schroeder and Lieth, 2004). DO concentrations less than $5 \mathrm{mg} \cdot \mathrm{L}^{-1}$ can lead to reduced root respiration and can result in the development of adventitious roots (Holtman et al.,
2014). DO is necessary for nitrification in aquaponic systems; concentrations near saturation promote aerobic bacteria and nitrification whereas depleted levels promote anaerobic bacteria and denitrification (Wongkiew et al., 2017; Zhen et al., 2015). Accurate measurement of DO helps identify hypoxic zones even in seemingly well-aerated solutions.

DO can be measured using three methods: iodometric titration, membrane diffusion (electrochemical), and fluorescence quenching (optical) (Tai et al., 2011; Zaitsev et al., 2018). Iodometric titration is a colorimetric titration and is labor intensive. More than eight companies sell a DO meter that uses optical technology, and more than 12 companies sell a meter with electrochemical technology. The meters tested in our review represent about $20 \%$ of the electrochemical DO meters available. Meters using electrochemical technology are less expensive than optical meters. With electrochemical meters, DO crosses a semipermeable membrane, is reduced at the cathode, and produces a voltage difference with the anode that is proportional to oxygen concentration (Parra et al., 2018).

There are two types of electrochemical technology. Polarographic sensors have a gold cathode and silver anode that are polarized temporarily at $0.8 \mathrm{~V}$ during measurement. Galvanic sensors have a silver cathode and zinc anode that are polarized constantly even when the meter is powered off (Wei et al., 2019). Polarographic electrodes require a warmup period of up to $15 \mathrm{~min}$. Galvanic electrodes do not require a warmup period, but constant polarization decreases the lifetime of the electrode.

Sensor technology determines price. Galvanic sensors are typically less expensive than polarographic sensors, which are less expensive than optical sensors. Optical sensors typically have a faster response and greater res-

\begin{tabular}{llll}
\hline $\begin{array}{l}\text { Units } \\
\begin{array}{l}\text { To convert U.S. to SI, } \\
\text { multiply by }\end{array}\end{array}$ & U.S. unit & SI unit & $\begin{array}{l}\text { To convert SI to U.S., } \\
\text { multiply by }\end{array}$ \\
\hline 29.5735 & $\mathrm{fl} \mathrm{oz}$ & $\mathrm{mL}$ & 0.0338 \\
0.3048 & $\mathrm{ft}$ & $\mathrm{m}$ & 3.2808 \\
3.7854 & $\mathrm{gal}$ & $\mathrm{L}$ & 0.2642 \\
0.001 & $\mathrm{ppm}$ & $\mathrm{g} \cdot \mathrm{L}^{-1}$ & 1000 \\
1 & $\mathrm{ppm}$ & $\mathrm{mg} \cdot \mathrm{L}^{-1}$ & 1 \\
$\left({ }^{\circ} \mathrm{F}-32\right) \div 1.8$ & ${ }^{\circ} \mathrm{F}$ & ${ }^{\circ} \mathrm{C}$ & $\left({ }^{\circ} \mathrm{C} \times 1.8\right)+32$ \\
\hline
\end{tabular}




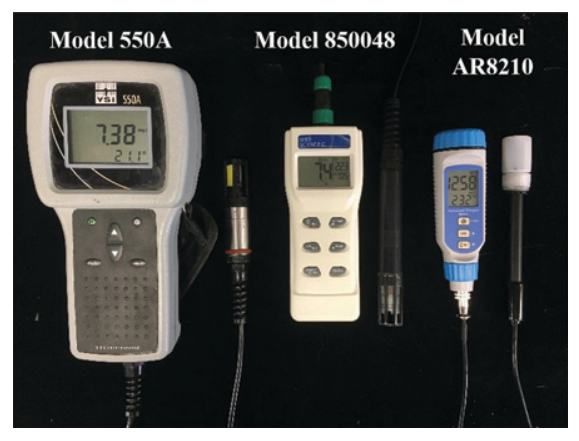

Fig. 1. Meter and electrode relative size comparisons of the YSI 550A (Yellow Springs, Inc., Yellow Springs, OH), Sper 850048 (Sper Scientific, Scottsdale, AZ), and Smart Sensor Roeam AR8210 (Smart Sensor, Dongguan, China) dissolved oxygen meters.

olution than polarographic and galvanic sensors. We evaluated DO meters at three price points for the accuracy, stability, and response time across salinity and temperature.

\section{Materials and methods}

Meters. Three hand-held DO meters were evaluated: the YSI 550A (YSI) was manufactured by Yellow Springs, Inc. (Yellow Springs, OH); the Sper 850048 (Sper), by Sper Scientific (Scottsdale, AZ); and the Roeam AR8210 (Smart Sensor) by Smart Sensor (Dongguan, China). The meters are as shown in Fig. 1 and their specifications are as shown in Table 1.

Electrode restoration. The electrodes were cleaned and the membranes were replaced on each meter to restore their measurement responses after prolonged storage. The electrode cathode and anode were sanded as needed to remove oxidation, and fresh electrolyte (sodium sulfate and potassium chloride salt solution from a manufacturer) was added to each electrode head. This procedure restores "as-new" functionality and should be done every few months during frequent use.

Calibration. The YSI has a built-in electrode storage chamber that provides a saturated oxygen environment. Single-point 100\% oxygen saturation is achieved by placing a few milliliters of water into the chamber, navigating to the calibration menu, and allowing the instrument to stabilize.

The Sper also uses a single-point calibration, but without a closed chamber. The manufacturer recommends that the electrode be placed in a wellventilated area for a few minutes until the measurement is stabilized.

Smart Sensor recommends a twopoint calibration method of their meter at $0 \%$ and $100 \%$ DO. The $100 \%$ saturated solution was made by aerating a beaker of tap water with ambient air via an air pump with a flow rate of $200 \mathrm{~mL} \cdot \mathrm{min}^{-1}$. The $0 \%$ DO solution was made by filling a beaker with tap water and bubbling nitrogen gas through the solution at $200 \mathrm{~mL} \cdot \mathrm{min}^{-1}$ to purge any DO.

Atmospheric pressure and solution salinity have large effects on DO. All three meters allowed for manual input of altitude $(1400 \mathrm{~m}$; Logan, UT) and salinity conditions. All instruments compensate for solution temperature using internal temperature sensors.

Measurements of accuracy AND STABILITY. Accuracy was evaluated by comparing the DO measurements to theoretical saturation levels. Saturation levels were calculated from current environmental conditions using DOTABLES software version 3.6 from the United States Geological Survey (U.S. Geological Survey, 2018). Meters were tested in freshwater $\left(0 \mathrm{~g} \cdot \mathrm{L}^{-1} \mathrm{NaCl}\right)$ and seawa$\operatorname{ter}\left(35 \mathrm{~g} \cdot \mathrm{L}^{-1} \mathrm{NaCl}\right)$, and at three temperatures $\left(12,22\right.$, and $\left.38^{\circ} \mathrm{C}\right)$ to span the specified ranges of the meters. An ice bath and hot plate were used to change water temperature. All measurements were made in a $1-\mathrm{L}$ beaker of with $1 \mathrm{~L}$ tap water aerated with ambient air via a bubbler at 200 $\mathrm{mL} \cdot \mathrm{min}^{-1}$ and stirred on a stir plate at $300 \mathrm{rpm}$. The stabilization time was recorded as the time to reach a stable reading for $5 \mathrm{~s}$ at a precision of one (Smart Sensor, Sper, and YSI) and two (YSI) decimal places. Measurements were made at the final stabilized DO measurement and were repeated five times under each condition.

Measurements were analyzed using analysis of variance and Tukey's honestly significant difference post hoc tests in $\mathrm{R}$ statistical software ( $\mathrm{R}$ Core Team, 2020).

\section{Results}

Stable measurements were not obtained from the Smart Sensor meter because the displayed value fluctuated constantly by more than $50 \%$. Further tests were thus not conducted with the Smart Sensor meter.

In freshwater at 12 and $22^{\circ} \mathrm{C}$, both the YSI and Sper meters measured a DO concentration $4 \%$ below the theoretical value, as shown in Fig. 2. At $38^{\circ} \mathrm{C}$ in freshwater, the YSI measured 13\% low and the Sper measured $13 \%$ high. In saline water at $12^{\circ} \mathrm{C}$, the YSI was within $1 \%$ of the theoretical DO concentration whereas the Sper measured $8 \%$ low. At $22^{\circ} \mathrm{C}$ in saline water, the YSI measured $7 \%$ low and the Sper measured 3\% low. At $38^{\circ} \mathrm{C}$ in saline water, the YSI measured $14 \%$ low whereas the Sper measured $14 \%$ high in relation to the

Table 1. Sensor types, current prices, and temperature and accuracy ranges of the YSI 550A (Yellow Springs, Inc., Yellow Springs, OH), Sper 850048 (Sper Scientific, Scottsdale, AZ), and Smart Sensor Roeam AR8210 (Smart Sensor, Dongguan, China) dissolved oxygen (DO) meters evaluated in the study.

\begin{tabular}{|c|c|c|c|c|c|}
\hline $\begin{array}{l}\text { Manufacturer and } \\
\text { model }\end{array}$ & Sensor & 2021 Price (USD) & Temp range $\left({ }^{\circ} \mathrm{C}\right)^{\mathrm{z}}$ & $\begin{array}{l}\text { DO measurement } \\
\text { range }\left(\mathrm{mg} \cdot \mathrm{L}^{-1}\right)^{\mathrm{z}}\end{array}$ & $\begin{array}{l}\text { DO measurement } \\
\text { accuracy }\end{array}$ \\
\hline YSI $550 \mathrm{~A}$ & Polarographic & 875 & -5 to 45 & $\begin{array}{r}0.00-20.00 \\
20.00-50.00\end{array}$ & $\begin{array}{l} \pm 2 \% \\
\pm 6 \%\end{array}$ \\
\hline $\begin{array}{c}\text { Smart Sensor } \\
\text { AR8210 }\end{array}$ & Polarographic & 99 & $0-40$ & $0.00-20.00$ & $\pm 0.4 \mathrm{mg} \cdot \mathrm{L}^{-1}$ \\
\hline
\end{tabular}

${ }^{\mathrm{z}}\left(\mathrm{l} .8 \times{ }^{\circ} \mathrm{C}\right)+32={ }^{\circ} \mathrm{F}, \mathrm{l} \mathrm{mg} \cdot \mathrm{L}^{-1}=1 \mathrm{ppm}$. 


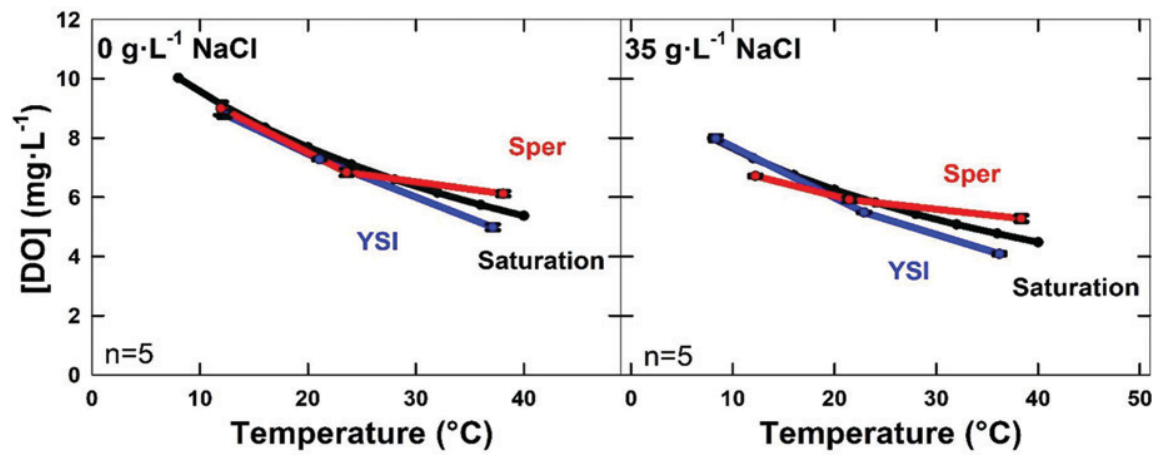

Fig. 2. Dissolved oxygen (DO) measurements of the YSI 550A (Yellow Springs, Inc., Yellow Springs, OH) and Sper 850048 (Sper Scientific, Scottsdale, AZ) meters compared with the calculated theoretical maximum DO levels at saturation across three temperatures $\left(12,22\right.$, and $38^{\circ} \mathrm{C}$ ) and two salinities $\left[0\right.$ and $35 \mathrm{~g} \cdot \mathrm{L}^{-1}$ sodium chloride $(\mathrm{NaCl})]$. Significance was tested using analysis of variance and Tukey's post hoc test. Error bars represent SD, $\mathrm{n}=5 .\left(1.8 \times{ }^{\circ} \mathrm{C}\right)+32={ }^{\circ} \mathrm{F}, \mathrm{l}$ $\mathrm{mg} \cdot \mathrm{L}^{-1}=1 \mathrm{ppm}, 1 \mathrm{~g} \cdot \mathrm{L}^{-1}=1000 \mathrm{ppm}$. theoretical DO concentration at saturation.

The YSI meter stabilized about 5 $s$ faster on average than the Sper meter to $0.1 \mathrm{mg} \cdot \mathrm{L}^{-1} \mathrm{DO}$, regardless of salinity, as shown in Fig. 3. Stabilization time of the YSI meter to $0.1 \mathrm{mg} \cdot \mathrm{L}^{-1}$ DO increased significantly from 9.5 to $11.4 \mathrm{~s}$ between 12 and $38^{\circ} \mathrm{C}$ in freshwater $(P=0.03)$ and from 9.8 to $12 \mathrm{~s}$ in saline water $(P=0.02)$. There was no significant difference in stabilization

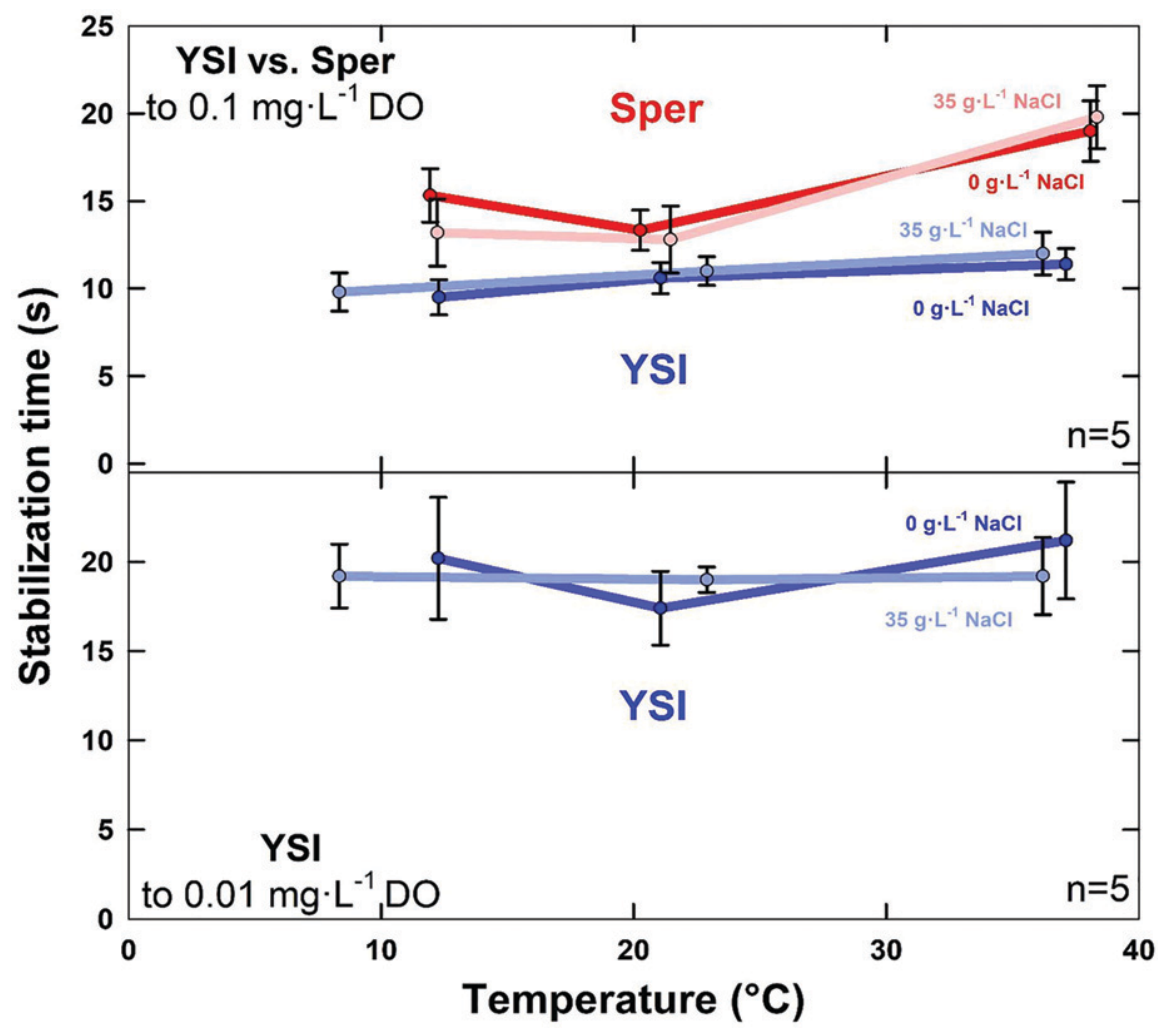

Fig. 3. Stabilization times for the YSI 550A (Yellow Springs, Inc., Yellow Springs, $\mathrm{OH}$ ) and Sper 850048 (Sper Scientific, Scottsdale, AZ) meters to 0.1 and 0.01 $\mathrm{mg} \cdot \mathrm{L}^{-1}$ dissolved oxygen (DO) levels across three temperatures $(\approx 12,22$, and $\left.38{ }^{\circ} \mathrm{C}\right)$ and two salinities $\left[0\right.$ and $35 \mathrm{~g} \cdot \mathrm{L}^{-1}$ sodium chloride $\left.(\mathrm{NaCl})\right]$. Significance was tested using analysis of variance and Tukey's post hoc test. Error bars represent $\mathrm{SD}, \mathrm{n}=5 .\left(1.8 \times{ }^{\circ} \mathrm{C}\right)+32={ }^{\circ} \mathrm{F}, 1 \mathrm{mg} \cdot \mathrm{L}^{-1}=1 \mathrm{ppm}, 1 \mathrm{~g} \cdot \mathrm{L}^{-1}=1000 \mathrm{ppm}$. times to $0.01 \mathrm{mg} \cdot \mathrm{L}^{-1} \mathrm{DO}$ across temperatures for the YSI meter regardless of salinity. In freshwater, stabilization times for the Sper meter differed $(P<$ 0.001 ) among the measured temperatures, with the shortest stabilization time occurring at $22^{\circ} \mathrm{C}$. The Sper meter took significantly longer $(P<$ 0.001 ) to stabilize to $0.1 \mathrm{mg} \cdot \mathrm{L}^{-1} \mathrm{DO}$ in saline water at $38^{\circ} \mathrm{C}$ compared with lower temperatures, where no differences in stabilization times were observed.

\section{Discussion}

The YSI, Sper, and Smart Sensor meters are designed to be accurate across a wide range of environments. Oxygen has an uptake rate greater than the sum of all other plant nutrients and nearly 5 -fold faster than that of nitrogen (Ingestad and Agren, 1988; Wen and Zhong, 1995). This high uptake rate leads to fast oxygen consumption from solution, which necessitates fast-responding meters to monitor DO levels. The meters evaluated can also measure DO under supersaturated conditions, which may be beneficial to hydroponic and aquaponic growers with oxygen-enriched waters to supplement high uptake rates (Bar-Yosef and Lieth, 2013; Goto et al., 1996). Langenfeld and Bugbee (2021) used the YSI meter to measure supersaturated DO conditions from nanobubbles.

The Smart Sensor meter was not stable in our tests despite multiple calibrations across several trials. Touching the electrode housing to the side of a beaker caused the measurement to change more than $50 \%$. We discontinued testing of the Smart Sensor meter after a lack of repeatable results. These results may not be representative of all Smart Sensor AR8210 DO meters, but they demonstrate reliability problems with the meter in our study.

The accuracies of both the YSI and Sper meters were similar at 0.1 $\mathrm{mg} \cdot \mathrm{L}^{-1} \mathrm{DO}$, with the YSI meter providing an extra digit of precision. Accuracy was slightly outside the ranges specified by both manufacturers, especially at $38^{\circ} \mathrm{C}$. Increased probe sensitivity has been found to correlate directly with temperature, which may compound errors at the upper end of the meter operating ranges (Mackereth, 1964). YSI sells a new model of the 550A (Pro20i) that has increased 
accuracy and the ability to switch between galvanic and polarographic electrodes, which can extend the service lifetime of the meter. Deposition of metals on electrodes increases with age and becomes the primary source of inaccurate readings. All probes were restored by sanding off visible oxidation before testing, but incomplete removal of oxidation products may have contributed to decreased accuracy (Lee and Tsao, 1979).

The YSI meter had a faster stabilization time (10 s) than the Sper meter (15 s), which is important in rapidly changing environments or when making multiple measurements. Solution temperatures at the upper end of the operating ranges of the meters were associated with increased stabilization times, which is contrary to the theory of fast oxygen diffusion through membranes at elevated temperatures, but in line with the increased sensitivity discussed earlier (Han and Bartels, 1996). Solubility of oxygen also decreases with increasing temperature, which may lead to increased errors. Salinity appeared to have little effect on stabilization times, suggesting both meters can be used in freshand saltwater.

Frequent testing of DO in horticultural crops helps to maintain an optimal root zone environment for maximum productivity. Both the YSI and Sper meters were accurate hand-held instruments at two common salinities and within their specified temperature ranges. The Sper meter is limited to $0.1 \mathrm{mg} \cdot \mathrm{L}^{-1}$ precision and has a shorter effective lifetime than a polarographic electrode. The YSI meter has a longer warmup period as a result of its polarographic electrode. These characteristics must be weighed against price (USD350 vs. USD875, respectively) to select the most appropriate meter for a given task. The results of this study may be beneficial to horticultural growers in selecting meters to measure DO concentrations.

\section{Literature cited}

Al-Rawahy, M.S., S.A. Al-Rawahy, Y.A. Al-Mulla, and S.K. Nadaf. 2019. Influence of nutrient solution temperature on its oxygen level and growth, yield and quality of hydroponic cucumber. J. Agr. Sci. 11:75-92, doi: 10.5539/jas.v1ln3p75.

Bar-Yosef, B. and J.H. Lieth. 2013. Effects of oxygen concentration in solution and uptake rate by roots on cut roses yield, and nutrients and sugars content in leaves. Scientia Hort. 155:49-55, doi: 10.1016/j.scienta.2013.03.002.

Ben-Noah, I. and S.P. Friedman. 2018. Review and evaluation of root respiration and of natural and agricultural processes of soil aeration. Vadose Zone J. 17:1-47, doi: 10.2136/vzj2017.06.0119.

Goto, E., A.J. Both, L.D. Albright, R.W. Langhans, and A.R. Leed. 1996. Effect of dissolved oxygen concentration on lettuce growth in floating hydroponics. Acta Hort. 440:205-210, doi: 10.17660/ ActaHortic.1996.440.36.

Han, P. and D.M. Bartels. 1996. Temperature dependence of oxygen diffusion in $\mathrm{H}_{2} \mathrm{O}$ and $\mathrm{D}_{2} \mathrm{O}$. J. Phys. Chem. 100:5597-5602, doi: 10.1021/jp952903y.

Holtman, W.L., B.J. Oppedijk, M. Vennik, and B. van Duijn. 2014. Low oxygen stress in horticultural practice, p. 381-394. In: J. van Dongen and F. Licausi (eds.). Low-oxygen stress in plants. Plant Cell Monographs. Springer-Verlag Wien, Heidelberg, Germany.

Ingestad, T. and G.I. Agren. 1988. Nutrient uptake and allocation at steady-state nutrition. Physiol. Plant. 72:450-459, doi: $10.1111 / \mathrm{j} .1399$ 3054.1988.tb09150.x.

Langenfeld, N. and B. Bugbee. 2021. Dissipation rates of oxygen nanobubbles in recirculating systems. Utah State Univ. Crop Physiol. Lab Techniques Instrum. 19:1-3.

Lee, Y.H. and G.T. Tsao. 1979. Dissolved oxygen electrodes. Adv. Biochem. Eng. Biotechnol. 13:35-86.
Mackereth, F.J.H. 1964. An improved galvanic cell for determination of oxygen concentrations in fluids. J. Sci. Instrum. $41: 38-41$.

Parra, L., G. Lloret, J. Lloret, and M. Rodilla. 2018. Physical sensors for precision aquaculture: A review. Sensors (Basel) 18:3915-3923, doi: 10.1109/ JSEN.2018.2817158.

R Core Team. 2020. R: A language and environment for statistical computing. $\mathrm{R}$ Foundation for Statistical Computing, Vienna, Austria.

Schroeder, F.G. and J.H. Lieth. 2004. Gas composition and oxygen supply in the root environment of substrates in closed hydroponic systems. Acta Hort. 644:299-305, doi: 10.17660/ActaHortic.2004.644.40.

Tai, H., Y. Yang, and S. Liu. 2011. A review of measurement methods of dissolved oxygen in water. Proc. Intl. Conf. Computer Comput. Technol. 2:569-576.

U.S. Geological Survey. 2018. DOTABLES. U.S. Geological Survey, Reston, VA.

Wei, Y., Y. Jiao, D. An, D. Li, W. Li, and Q. Wei. 2019. Review of dissolved oxygen detection technology: From laboratory analysis to online intelligent detection. Sensors (Basel) 19:3995-4033, doi: $10.3390 / \mathrm{s} 19183995$.

Wen, Z. and J. Zhong. 1995. A simple and modified manometric method for measuring oxygen uptake rate of plant cells in flask cultures. Biotechnol. Tech. 9:521-526, doi: 10.1007/BF00159570.

Wongkiew, S., Z. Hu, K. Chandran, J.W. Lee, and S.K. Khanal. 2017. Nitrogen transformations in aquaponics systems: A review. Agr. Eng. 76:9-19, doi: 10.1016/j.aquaeng.2017.01.004.

Zaitsev, N.K., V.I. Dvorkin, P.V. Melnikov, and A.E. Kozhukhova. 2018. A dissolved oxygen analyzer with an optical sensor. J. Anal. Chem. 73:102-108, doi: 10.1134/S1061934818010136.

Zhen, H., J.W. Lee, K. Chandran, S. Kim, A.C. Brotto, and S.K. Khanal. 2015. Effect of plant species on nitrogen recovery in aquaponics. Bioresour. Technol. 188:92-98, doi: 10.1016/j.biortech.2015.01.013. 